\title{
RNA METABOLISM IN THE GOLDFISH RETINA DURING OPTIC NERVE REGENERATION ${ }^{1,2}$
}

\author{
Harry R. Burrell, Linda A. Dokas and Bernard W. Agranoff \\ Neuroscience Laboratory, Mental Health Research Institute and Department of Biological Chemistry, \\ The University of Michigan, Ann Arbor, MI 48109, U.S.A.
}

(Received 31 August 1977. Accepted 24 November 1977)

\begin{abstract}
In goldfish, regeneration of the optic nerve following axotomy is accompanied by changes in retinal RNA metabolism. Approximately 4 days after unilateral optic nerve crush, there is an increased uptake of ${ }^{3} \mathrm{H}$-labeled precursors of RNA into cells of the retina as well as an increase in labeling of total retinal RNA following incubation for $3-4 \mathrm{~h}$ in vitro. Subfractionation indicates that the resultant labeled free ribosomal RNA has a much higher specific activity than that from membrane-bound ribosomes in post-crush, as compared to normal retinas. Total retinal RNA content also increases, reaching a peak value about 8 days after axotomy, coincident with the time of observed maximum labeling of ribosomal RNA. No change in the total protein or DNA content of the retina is detected during this period as a result of the optic nerve crush.

Saturating amounts of uridine or adenosine in the medium eliminate the general effects of enhanced uptake of the precursors on RNA labeling. Elevated labeling of poly(A)-containing RNA in retinal cytoplasm is nevertheless detected 10-14 days after optic nerve crush with no change in the labeling of the polyadenylate segment. A decrease in the labeling of poly(A)-containing nuclear RNA, from a significantly greater amount than that of normal retinas to a significantly lower one, occurs during the period of observed increased labeling of cytoplasmic poly(A)-containing RNA. The results indicate that in addition to changes in RNA precursor metabolism, optic nerve regeneration is characterized by alterations in the labeling of free and membrane-bound retinal ribosomes as well as in the posttranscriptional processing of messenger RNA.
\end{abstract}

AXONAL REGENERATION following injury can serve as a model system for the study of neuronal plasticity and gene expression, processes which are of importance in the development and function of the nervous system. The goldfish optic nerve, composed of the axons of retinal ganglion cells, is especially amenable for such investigations, as it is an anatomically well defined structure which is easily accessible for experimental manipulation. Upon intraorbital crush of the optic nerve, the distal portion of the nerve (that section separated from the perikaryon) degenerates. This is then followed by axonal regrowth and reinnervation of the optic tectum by the new fibers in a highly specific spatial pattern (JACOBSON \& GAZE, 1965). Returned visual function is observed several weeks post-crush in these fish (SPRINGer \& AGRanofF, 1977).

A number of ultrastructural changes that accompany retinal ganglion cell hypertrophy (MURRAY \&

${ }^{1}$ A preliminary report of this work was presented at the 61st Meeting of the Federation of American Societies for Experimental Biology, April, 1977.

${ }^{2}$ This work was supported by NIMH grants 07417 and 12506. HRB and LAD are postdoctoral trainees of NIMH Interdisciplinary Training Program.

Abbreviations used: Poly(A), polyadenylate; oligo(dT), oligodeoxythymidylate; TCA, trichloroacetic acid; SDS. sodium dodecyl sulfate; tRNA, transfer RNA; mRNA messenger RNA; hnRNA, heterogeneous nuclear RNA; TKM, $10 \mathrm{mM}-\mathrm{Tris}-\mathrm{HCl}$ ( $\mathrm{pH} 7.6$ ), containing $0.5 \mathrm{M}-\mathrm{KCl}$ and $1 \mathrm{mM}-\mathrm{MgCl}_{2}$.
GrafsTEIN, 1968) after optic nerve lesion in the goldfish, including an increase in nucleolar size and in cytoplasmic basophilia (MURRAY \& GRAFSTEIN, 1969 ), probably represent an altered ribosomal state (MURRAY \& FOREMAN, 1971). These perikaryal responses are consistent with an involvement of RNA and protein metabolism in axon regeneration, a suggestion that has received support from previous studies in the goldfish optic system, as well as in regeneration studies of other vertebrate motor and sensory neuronal pathways (for reviews, see CraGg 1970; Lieberman, 1971; Grafstein, 1975). Radioautographic analyses of goldfish retina have shown that there is an increased incorporation of labeled precursors into both RNA (MURRAY, 1973) and protein (MURRAY \& GRafstein, 1969) of ganglion cells following optic tract transection. Enhanced labeling of retinal microtubular protein occurs following optic nerve crush, suggesting a selective increase in synthesis of this important axon structural component (Heacock \& AGRANOFF, 1976). The report of an increased amount of radioactive low molecular weight RNA found in the newly reinnervated optic tectum after intraocular injection of labeled uridine may reflect an elevated transport of RNA or its precursors by the regenerating axons (INGOGLIA \& TuliszEwsKI, 1976). Ongoing RNA synthesis may be a prerequisite for the characteristic chromatolytic response of neuronal cell bodies to axotomy, since it is reportedly inhibited by actinomycin $\mathrm{D}$ if the drug 
is administered within $9-12 \mathrm{~h}$ of surgery (TORvIK \& SkJÖRTEN, 1974). These ultrastructural, histological and biochemical data support the conclusion that alterations in transcription and, subsequently, in translation are an intrinsic feature of the neuronal regenerative response.

The purpose of the present report is to examine in greater detail retinal RNA metabolism during regeneration of the optic nerve. Knowledge of specific changes in neuronal RNA during re-establishment of retinotectal connections should permit a better understanding of the more generalized phenomena of directed cell growth and synaptogenesis.

\section{EXPERIMENTAL PROCEDURES}

Materials. $\left[{ }^{3} \mathrm{H}\right]$ Uridine and $\left[{ }^{3} \mathrm{H}\right]$ adenosine (each 25-30 $\mathrm{Ci} / \mathrm{mmol}$ ) were obtained from New England Nuclear Corporation (Boston, MA), Cordycepin and bovine testis hyaluronidase were products of Sigma Chemical Company (St. Louis, MO). Oligo(dT)-cellulose (type T-3) was from Collaborative Research lnc. and was pretreated with Escherichia coli tRNA before use (BANTLE et al., 1976). DNase 1 (RNase-free), RNase $A$ and RNase $T l$ were obtained from Worthington Biochemicals (Freehold, NJ). Schleicher and Schuell type BA85 filters were used in the nitrocellulose filter-binding assay.

Methods. Goldfish (Carassius auratus), 6-7 cm in body length (Ozark Fisheries. Stoutland, MO) were anesthetized with tricaine methane sulfonate (Finquel, Ayerst Laboratories) prior to intraorbital crush of the right optic nerve (SPRINGer \& AGRanOFF, 1977). The right eye was not removed. The left optic nerve remained intact, allowing the left retina to serve as a control (normal). Following surgery, goldfish were stored in groups of 50-80 in 30 gallon tanks at $20^{\circ}-22^{\circ} \mathrm{C}$ and were fed daily.

In vitro labeling of retinal $R N A$. Both retinas were removed at various times after unilateral nerve crush as described previously (Heacock \& AGRanOFF, 1976). Groups of 5 or more right or left retinas were incubated for $3-4 \mathrm{~h}$ in $0.2 \mathrm{ml}$ per retina of Dunlop's medium (DUNLop et al., 1974): $25 \mathrm{~mm}-N$-2-hydroxyethylpiperazine- $N^{\prime}-2-$ ethanesulfonicacid(HEPES), $1.3 \mathrm{mM}-\mathrm{MgSO}_{4}, 2.6 \mathrm{mM}-\mathrm{CaCl}_{2}$. $1.2 \mathrm{~mm}-\mathrm{K}_{2} \mathrm{HPO}_{4}, 5.9 \mathrm{~mm}-\mathrm{KCl}, 107 \mathrm{~mm}-\mathrm{NaCl}, 12 \mathrm{~mm}$-glucose and $\mathrm{NaOH}$ to $\mathrm{pH} 7.4$, with labeled uridine or adenosine as specified. Incubations were performed at $25 \mathrm{C} \pm 1^{\circ} \mathrm{C}$ in a Dubnoff metabolic shaker under a $95 \% \mathrm{O}_{2}-5 \% \mathrm{CO}_{2}$ atmosphere.

The incubations were terminated by the addition to the chilled medium of a volume of $4 \mathrm{~mm}$ unlabeled uridine or adenosine equal to that of the incubation medium followed by washing the retinas in a excess of the same solution at $4{ }^{\circ} \mathrm{C}$. Where indicated in the Results, retinas were further incubated for $20 \mathrm{~min}$ in fresh medium (without precursor) containing $0.4 \mathrm{mg} / \mathrm{ml}$ of hyaluronidase and washed again as above. This treatment removed the small amount of RNA precursor which was nonspecifically retained in the vitreous.

Retinas were homogenized at $4 . \mathrm{C}$ in $0.4 \mathrm{ml}$ of $\mathrm{H}_{2} \mathrm{O}$ containing $10 \mu \mathrm{g} / \mathrm{ml}$ of polyvinylsulfate per retina. In experiments in which nuclear and cytoplasmic fractions were analyzed separately, homogenates were prepared at $4^{\circ} \mathrm{C}$ in $0.4 \mathrm{ml}$ per retina of $10 \mathrm{~mm}$-sodium phosphate buffer (pH 6.5) containing $0.32 \mathrm{M}$-sucrose, $0.01 \%$ polyvinylsulfate, $4 \mathrm{~mm}-\mathrm{MgCl}_{2}$, and $25 \mathrm{~mm}-\mathrm{KCl}$, with 12 strokes of a
Teflon-glass homogenizer (clearance of $300 \mu \mathrm{m}$ ). After centrifugation of the homogenate at $1000 \mathrm{~g}$ for $10 \mathrm{~min}$, the resulting pellet was washed with an equal volume of the homogenization buffer and recentrifuged. The combined. supernatant fractions of the two centrifugations were termed the 'cytoplasmic fraction' and the pellet. following resuspension in $3.0 \mathrm{ml}$ of the homogenization buffer, was termed the 'nuclear fraction." One-tenth volume of macaloid $(5 \mathrm{mg} / \mathrm{ml}$; JONES, 1976) was added to each of the fractions prior to storage at $-20 \mathrm{C}$

Free- and membrane-bound ribosomes were prepared essentially as described by Ramsey \& STEELE (1976) using goldfish retinas previously labeled in vitro with $\left[{ }^{3} \mathrm{H}\right]$ uridine. Non-ribosomal RNA and protein were removed by centrifuging the ribosome preparations through sucrose containing 0.5 M- $\mathrm{NH}_{4} \mathrm{Cl}$ (ZOMZFLY-Neurath \& RoBERTS, 1972). The purified ribosomes were resuspended in $50 \mathrm{~mm}-\mathrm{Tris}-\mathrm{HCl}$ ( $\mathrm{pH}$ 7.5), containing $25 \mathrm{~mm}-\mathrm{KCl}$ and $4 \mathrm{mM}-\mathrm{MgCl}_{2}$, and were stored at $-20 \mathrm{C}$.

Determination of DNA, RNA and protein. Nucleic acids were isolated from retinal homogenates using differential TCA extraction and hydrolysis (SANTEN \& AGRanofF, 1963). DNA was determined by a modified diphenylamine procedure (BurTon, 1968). RNA was measured by the orcinol reaction, adapted for microscale analysis (LIN \& SCHEIDE, 1969). Alternately, nucleic acids were estimated following extraction by absorbance at $260 \mathrm{~nm}$ (SANTEN \& AGranoff, 1963). The methods gave comparable results. Protein was determined by the method of Lowry et al. (1951), using bovine serum albumin as a standard.

Incorporation of ${ }^{3} \mathrm{H}$-labeled precursors of $R N A$ into TCA-soluble and TCA-insoluble fractions. Incorporation of the labeled precursors into total cell RNA, nuclear RNA or cytoplasmic RNA was measured by a modification of the fitter paper assay of MANS \& NovelLu (1961) with omission of the hot TCA wash. The filter paper discs containing the TCA-insoluble radioactivity were combusted in a Packard model 306 sample oxidizer. A portion of the combined TCA washes was extracted twice with ether prior to addition of $10 \mathrm{ml}$ of a toluene-based scintillant containing $26 \%$ Triton X-100 and radioactivity was determined by means of scintillation counting.

TCA-soluble radioactivity was also estimated after precipitation of a portion of each homogenate with $10 \mathrm{vol}$ of cold $10 \%$ TCA. Following centrifugation. the pellet was washed once with cold $10 \%$ TCA and recentrifuged. A portion of the combined ether-extracted supernatants was added to the toluene cocktail and counted as above.

Calculations. In many cases, it was convenient to express the difference between experimental and control samples as per cent change, that is, $(P C-N) / N \times 100$ where $P C$ is the value obtained for post-crush retina and $N$ is the value for normal retina. The error bars in each experiment represent S.E.M.; $P$ values were determined by Student's t-test.

Preparation of RNA. RNA was prepared from both cytoplasmic and nuclear fractions by a sequential extraction with phenol-chloroform-isoamyl alcohol under conditions shown to be optimal for the recovery of poly(A)-containing RNA (Lee et al., 1972; Perry et al.. 1972). The RNA was precipitated overnight at $-20 \mathrm{C}$ in 2 vol of $95 \%$ ethanol. Nuclear RNA was pelleted at $12,000 \mathrm{~g}$, then dissolved in $10 \mathrm{~mm}-T$ ris- $\mathrm{HCl}$ (pH 7.5 ) containing $10 \mathrm{~mm}-$ $\mathrm{MgCl}_{2}$ and $100 \mu \mathrm{g} / \mathrm{ml}$ of DNase 1 and incubated for $30 \mathrm{~min}$ at $37^{\circ} \mathrm{C}$. The RNA was reextracted as described above and reprecipitated. Purified RNA fractions possessed an 
$\mathrm{OD}_{260} / \mathrm{OD}_{280}$ ratio of approx 2. indicating the absence of significant protein contamination. They were dissolved in $10 \mathrm{~mm}-\mathrm{Tris}-\mathrm{HCl}(\mathrm{pH} \quad 7.6)$, containing $0.5 \mathrm{M}-\mathrm{KCl}$ and $1 \mathrm{mM}-\mathrm{MgCl}_{2}$ (TKM buffer) for analysis of poly(A)-containing RNA by nitrocellulose filter binding and for measurement of RNase-resistance, or in $0.01 \mathrm{M}-\mathrm{Tris}-\mathrm{HCl}(\mathrm{pH}$ 7.4), containing $0.5 \mathrm{M}-\mathrm{NaCl}$ and $0.5 \%$ SDS, for analysis of poly(A)-containing RNA by oligo(dT)-cellulose chromatography (LARKINS et al., 1976).

To prevent RNA degradation during the homogenization and purification procedures, glassware was rinsed in $0.1 \%$ diethylpyrocarbonate and sterilized by heating at $160^{\circ} \mathrm{C}$. Gloves were worn throughout the RNA extraction and analysis steps. All solutions were autoclaved before use. In addition. macaloid and polyvinylsulfate were added where noted to inhibit possible contaminating R Nase.

Anulysis of poly $(A)$-containing $R N A$ by nitrocellulose filter binding. Poly(A)-containing RNA is usually estimated by binding to nitrocellulose filters in the presence of high salt (BRAWERMAN, 1974) or by chromatography on oligo(dT)-cellulose (LaRkins et al., 1976). Although the latter method has been reported to be more specific (Brawerman. 1976), it has the disadvantage of being relatively expensive and time-consuming. Since our experimental design involved multiple analyses of small quantities of RNA of low specific activity, the nitrocellulose method was preferred.

Radioactivity in a portion of each RNA preparation was determined prior to nitrocellulose filtration. The remainder of the RNA was diluted with TKM buffer; the final RNA concentration was no more than $300 \mu \mathrm{g} / \mathrm{ml}$. The solution was passed slowly through a nitrocellulose filter which had been presoaked for at least $30 \mathrm{~min}$ in TKM buffer. The filter was washed with $10 \mathrm{ml}$ of the same buffer. dried and combusted in the sample oxidizer. Results, expressed as percent $\left[{ }^{3} \mathrm{H}\right]$ RNA bound to nitrocellulose filters, are assumed to represent the percentage of the total RNA in each fraction which contains polyadenylate sequences.

The validity of this method for estimation of poly (A)containing RNA was established by first comparing the abilities of nitrocellulose filters and oligo(dT)-cellulose to bind poly(Ai-containing RNA purified from cytoplasmic and nuclear fractions of goldfish retina. We next examined the binding of retinal RNA to nitrocellulose filters after incubation of the retinas in the presence of $\left[{ }^{3} \mathrm{H}\right]$ adenosine and cordycepin ( $3^{\prime}$-deoxyadenosine), an agent known to inhibit the attachment of polyadenylate sequences to nuclear heterogeneous RNA (DARNELL et al.. 1971), and consequently to inhibit the transport of $\mathrm{mRNA}$ to the cytoplasm (ADESN) et al., 1972).

To compare nitrocellulose filter binding and oligo(dT)cellulose chromatography, retinas were incubated with $\left[{ }^{3} \mathrm{H}\right]$ uridine $(10 \mu \mathrm{Ci} /$ retina $)$ and the cytoplasmic and nuclear RNA extracted. Each RNA preparation was divided in half; one portion was bound to nitrocellulose filters and the other analyzed by means of oligo(dT)-cellulose. The two methods agreed to within $2 \%$ of each other for cytoplasmic RNA For nuclear samples, nitrocellulose filters consistently bound 25 to $30 \%$ more labeled material than did oligo(dT)cellulose. This may be due to difference in the interactions of each matrix with polyadenylate sequences of varying lengths within hnRNA (MOLLOY et al., 1974).

As a second indication of the selectivity of nitrocellulose filter binding, a progressive loss of binding of $\left[{ }^{3} \mathrm{H}\right] \mathrm{RNA}$ to nitrocellulose filters was seen in both the cytoplasmic and nuclear fractions when retinal RNA was labeled in the presence of increasing amounts of cordycepin (Fig. 1). This is not due to an inhibition of $\left[{ }^{3} \mathrm{H}\right]$ adenosine uptake by cordycepin, since no decrease in TCA-soluble radioactivity was observed in these retinas. A decrease in labeled R Nase-resistant material (i.e. polyadenylate sequences), especially in the retinal cytoplasm, after treatment with cordycepin was also detected by the nitrocellulose filter
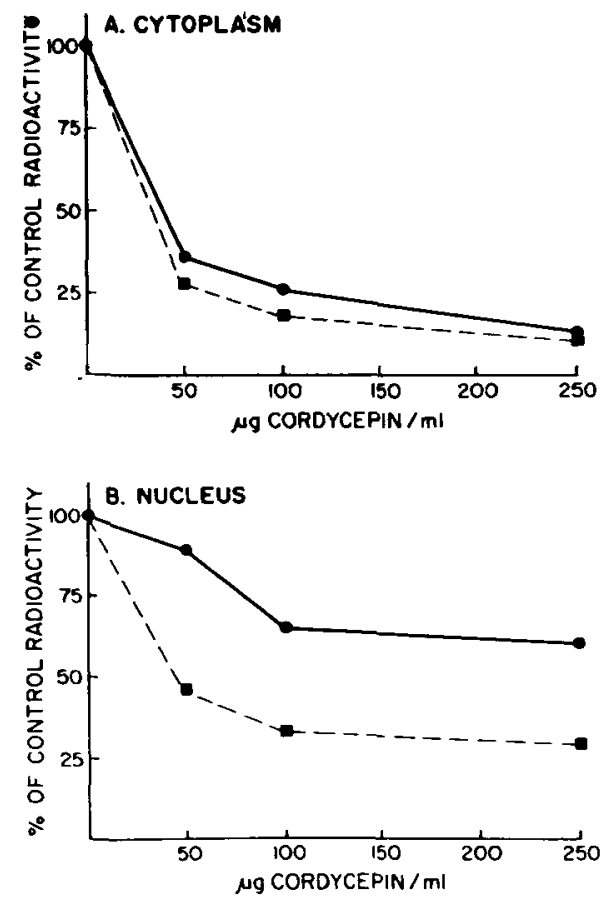

FiG. 1. Effect of cordycepin on the ${ }^{3} \mathrm{H}$-labeling of retinal cytoplasmic and nuclear poly(A)-containing RNA. Groups of 8 retinas were incubated for $4 \mathrm{~h}$ with increasing concentrations of cordycepin (3'-deoxyadenosine) and $5 \mu \mathrm{Ci}$ of $\left[{ }^{3} \mathrm{H}\right]$ adenosine per retina. Following incubation, cytoplasmic and nuclear RNAs were purified and bound to nitrocellulose filters as a measure of poly(A)-containing RNA. The labeling of polyadenylate sequences was determined by measuring RNase-resistant radioactivity bound to nitrocellulose filters following incubation of purified RNA fractions with RNase TI and RNase A. $100 \%$ represents 79,300 d.p.m. in bound cytoplasmic RNA and 1,015,200 d.p.m. in bound nuclear RNA. For RNaseresistant material, $100^{\circ} \%$ represents 15,300 d.p.m. (cytoplasmic RNA) and 94,000 d.p.m. (nuclear RNA). Total poly(A)-containing RNA, ——; RNase-resistant material. - _ - 1 -

assay (Fig. 1). Given the predominant biochemical action of cordycepin, that is, inhibition of synthesis of the polyadenylate "tail?" it can be inferred that nitrocellulose filter binding is capable of reliably monitoring changes in cellular poly(A)-containing RNA.

Measurement of RNase-resistance of RNA fractions. Samples, dissolved in TKM buffer, were incubated with $10 \mu \mathrm{g}$ of RNase $A$ and $2.5 \mu \mathrm{g}$ of R Nase Tl $\mathrm{ml}$ for $45 \mathrm{~min}$ at $37^{\circ} \mathrm{C}$. Following this $\mathrm{R}$ Nase digestion, samples were analyzed by nitrocellulose filter binding as described above. 


\section{RESULTS}

RNA, DNA and protein content of the goldfish retina during optic nerve regeneration

Since previous workers (LIEBERMAN; 1971; GrafSTEIN, 1975) have reported histological and ultrastructural evidence for changes in RNA and protein metabolism during nerve regeneration, it was of interest to measure these parameters in the axotomized goldfish retina. Because of variability in retinal size, RNA and protein values were normalized to that of DNA. No significant changes in the latter were detected in a preliminary examination of post-crush retinas during the time course of optic nerve regeneration. Fig. 2 shows the results of several such experiments. A significant increase $(20-25 \%, P<0.005)$ labelec aridine into the TCA-soluble precursor pool (Fig. 3). The differences were significant, both for RNA precursor uptake $(P<0.005)$ and for RNA labeling $(P<0.025)$. Following alkaline hydrolysis of the labeled RNA and chromatographic isolation of the resulting nucleotides, the specific activity of uridine and cytidine in 10 day post-crush retinal RNA was found to be approx $60 \%$ higher than that from normal retinas. Although labeling of cellular RNA in postcrush retinas returned to near control value by day 20, that of the RNA precursor pool remained significantly elevated (Fig. 3). An enhanced uptake was also observed using $\left[{ }^{3} \mathrm{H}\right]$ adenosine, but not with $\left[{ }^{3} \mathrm{H}\right]$ leucine. This effect in post-crush retinas appears therefore to be somewhat selective.

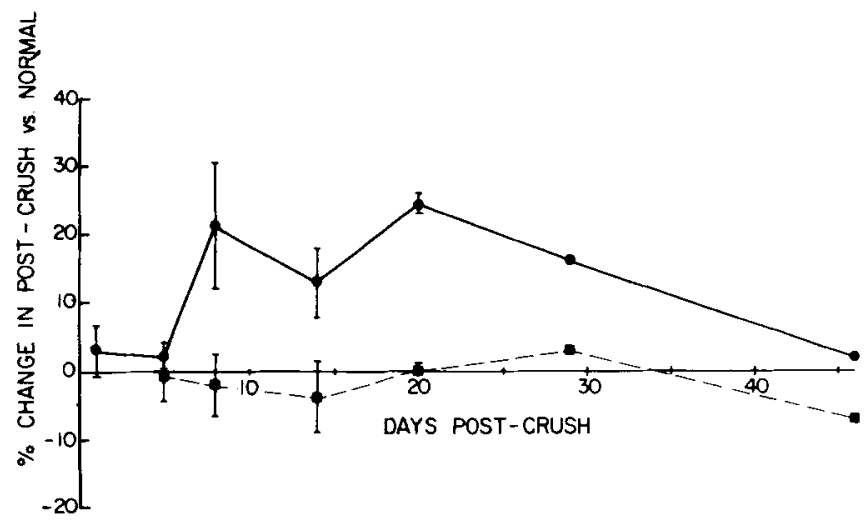

FIG. 2. RNA and protein content (normalized to DNA) in post-crush and normal retina. Protein was determined by the Lowry procedure; RNA and DNA were assayed by either orcinol/diphenylamine or by an $\mathrm{OD}_{260}$ method. Three or five paired groups, each containing 5 post-crush or normal retinas, were analyzed at 0-20 days following optic nerve crush. The values for 28 and 46 days after crush represent determinations made on 2 paired groups of 20 retinas each. Percent change was calculated as described in Experimental Procedures. Each normal retina contained $748 \pm 30 \mu \mathrm{g}$ protein, $30 \pm 1 \mu \mathrm{g}$ RNA, and $38 \pm 1 \mu \mathrm{g}$ DNA. RNA/DNA, ——— Protein/DNA, - - -

in retinal RNA appeared by the eighth day following axotomy. Cellular RNA content remained elevated through day 20 , then slowly returned to that of control retinas by day 46 . The protein content of post-crush retinas remained unchanged during this period. A large degree of variability was noted in the protein content of retinas one day following optic nerve crush, precluding a statistical comparison of the protein/DNA ratio with that of normal retinas.

\section{In vitro uptake of ${ }^{3} \mathrm{H}$-precursors}

Preliminary experiments established that isolated goldfish retinas incorporated $\left[{ }^{3} \mathrm{H}\right]$ uridine into TCAsoluble and insoluble material in a linear fashion for up to $4 \mathrm{~h}$. More than $95 \%$ of the TCA-insoluble radioactivity in these retinas was sensitive to RNase. When 8 day post-crush and control retinas were incubated with $\left[{ }^{3} \mathrm{H}\right]$ uridine, an enhanced labeling of TCA-insoluble material was seen (Fig. 3). However, there was also a similar increase in the uptake of

\section{Saturation of RNA precursor pools}

Since post-crush retinas exhibit an enhanced uptake of RNA precursors from the extracellular medium compared to normal retinas, it was not possible to draw conclusions from the above experiments regarding RNA labeling. To overcome possible precursor pool effects on RNA labeling, retinas were incubated with increasing amounts of unlabeled RNA precursor to the point that further decreasing the added precursor specific activity produced no further reduction in the specific activity of the labeled RNA precursor pool or of the resulting $\left[{ }^{3} \mathrm{H}\right] \mathrm{RNA}$. In further experiments on RNA labeling, we added $50 \mu \mathrm{g} / \mathrm{ml}$ of uridine to the incubation medium (final concentration $=2.05 \times$ $10^{-4} \mathrm{M}$ ), or $375 \mu \mathrm{g} / \mathrm{ml}$ of adenosine (final concentration $\left.=1.40 \times 10^{-3} \mathrm{M}\right)$. At these concentrations, the intracellular RNA precursor pools were saturated with unlabeled precursor.

About $20 \%$ of the residual TCA-soluble radioactivity remaining in the retinas was not affected by the 


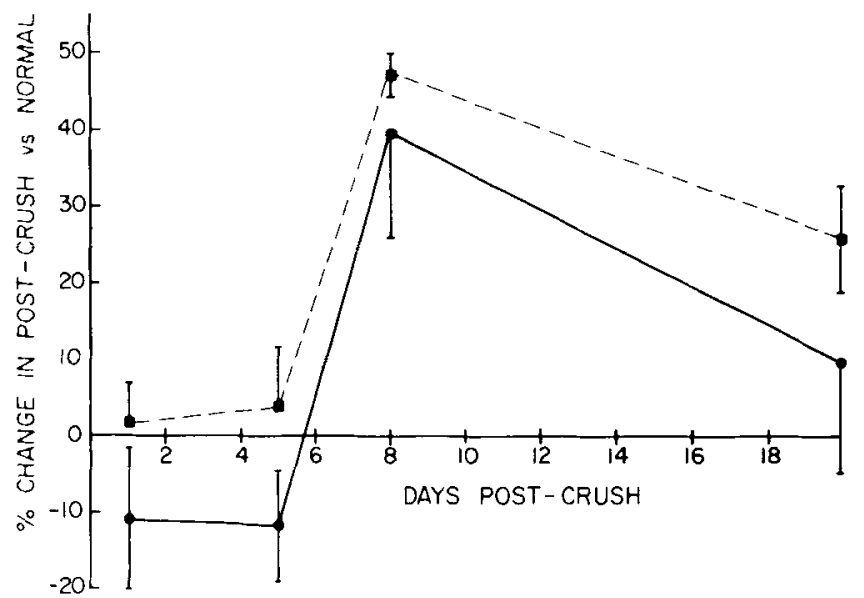

Fic. 3. Comparison of $\left[{ }^{3} \mathrm{H}\right]$ uridine uptake and incorporation into RNA by post-crush and normal retinas. Retinas were incubated for $3 \mathrm{~h}$ at $25 \mathrm{C}$ in a HEPES salts-glucose medium, containing $1.2 \mu \mathrm{Ci}\left[{ }^{3} \mathrm{H}\right]$ uridini per retina. Each point represents the per cent change in d.p.m./mg protein obtained from homogenates of 3 groups of 5 normal or 5 post-crush retinas. Each group of 5 normal retinas contained an average 478,000 d.p.m./mg protein (TCA-soluble) and 380,500 d.p.m./mg protein (TCA-precipitate). TCA-precipitable fraction (RNA), - - - : TCA-soluble fraction (RNA precursors),

addition of uridine. Adsorption of $\left[{ }^{3} \mathrm{H}\right]$ uridine could be reduced to $10-11 \%$ (comparable to that seen with $\left[{ }^{3} \mathrm{H}\right]$ adenosine) by incubation with hyaluronidase to free the retina from adhering vitreous. The result indicated that a significant amount of uridine is trapped in the vitreous, and treatment with hyaluronidase was therefore included in subsequent experiments.

\section{Poly $(A)$-containing $R N A$ of normal and post-crush retinas}

Addition of saturating amounts of unlabeled adenosine to the incubation medium eliminates both the increase in TCA-soluble radioactivity from added $\left[{ }^{3} \mathrm{H}\right]$ adenosine seen in post-crush retinas and increased labeling of cytoplasmic and nuclear RNA (Fig. 4). It was thus possible that changes in precursor pool size were responsible for the enhanced labeling of total RNA. However, as shown below, specific subclasses of RNA demonstrated differences between normal and postcrush retinas under saturating precursor conditions.

Of special interest because of its role as messenger RNA (BRAWERMAN, 1976), is poly(A)-containing RNA. After labeling of retinas in vitro with $\left[{ }^{3} \mathrm{H}\right]$ adenosine under saturating conditions, cytoplasmic and nuclear RNAs were extracted and bound to nitrocellulose filters. Fig. 4 demonstrates a large increase in the labeling of poly(A)-containing RNA in the cytoplasm of 13 day post-crush retinas. The effect was not seen in the nuclear poly(A)-containing RNA fraction. Some variability in the magnitude of increased cytoplasmic poly(A)-containing RNA labeling was noted in comparing results from different experiments. However, statistical analysis of a larger number of individual experiments $(\mathrm{N}=18)$ by the
Student's $t$-test showed an average increase on day 13 following optic nerve crush of $60.5 \%(P=0.01)$ for cytoplasmic poly(A)-containing RNA, when $\left[{ }^{3} \mathrm{H}\right]$ adenosine was the RNA precursor. Using RNase resistance as a measure of the amount of polyadenylate in RNA, no differences were found between 13 day post-crush and normal retinas in either the cytoplasmic or nuclear RNA fractions (Fig. 4). It should be noted that in order to measure the polyadenylate segment directly, retinas were incubated with high specific activity $\left[{ }^{3} \mathrm{H}\right]$ adenosine to insure that sufficient detectable radioactivity remained after RNase digestion.

Increased labeling of cytoplasmic poly(A)containing RNA is also seen in post-crush retinas when $\left[{ }^{3} \mathrm{H}\right]$ uridine is the precursor (Fig. 5A). The increase is first detected in the retinal cytoplasmic fraction at day 10 following optic nerve crush, with a peak at 2 weeks and a return to the control level of poly(A)-containing RNA by day 20. Each point in Fig. 5A represents the average value from three individual incubations of postcrush or normal retinas. The differences at days 10,13 , and 14 are statistically significant $(P \leqq 0.01)$. A more extensive analysis ( $N=10$ incubations) of day 14 post-crush and normal retinas with $\left[{ }^{3} \mathrm{H}\right]$ uridine as the RNA precursor yielded a difference of $64.3 \%(P<0.025)$ in the labeling of this RNA

The radiolabeling pattern of nuclear poly(A)containing RNA during optic nerve regeneration is quite different from that of the cytoplasmic species (Fig. 5B). There is a small but significant increase in nuclear labeled poly(A)-containing RNA on day 4 $(16.8 \pm 6.7 \% ; P=0.05)$ followed by an equally small but significant decrease by day $14(-21.2 \pm 5.6 \%$; 


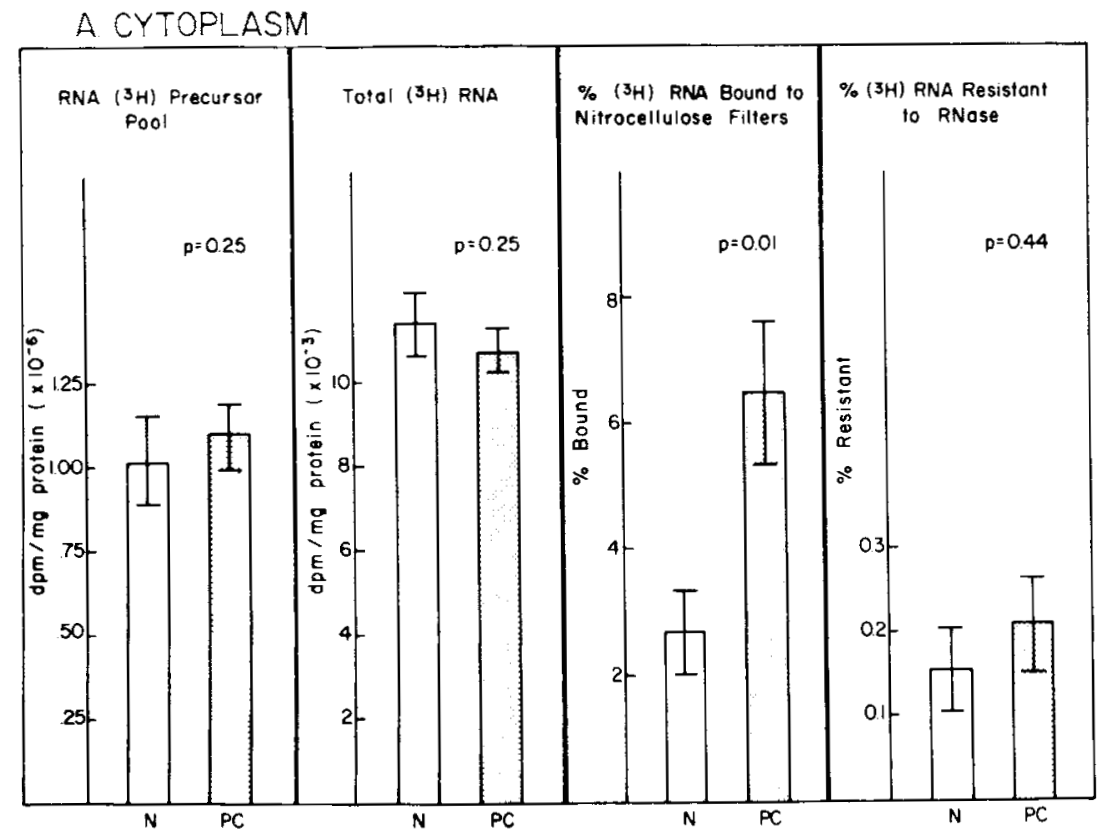

B. NUCLEI

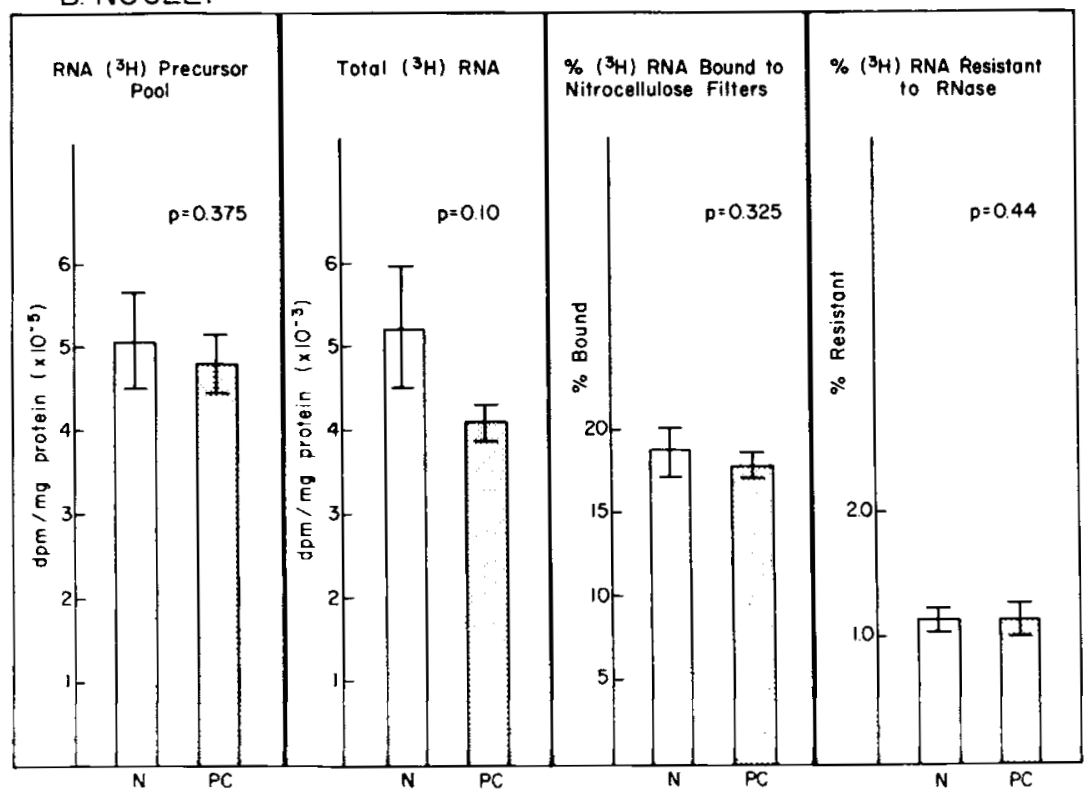

FIG. 4. Incorporation of $\left[{ }^{3} \mathrm{H}\right]$ adenosine into cytoplasmic and nuclear fractions of normal and 13-day postcrush retinas. Retinas were incubated as described in Fig. 3 with $2 \mu \mathrm{Ci}\left[{ }^{3} \mathrm{H}\right]$ adenosine per retina. Except in experiments to determine RNase resistance, all incubations contained saturating amounts of unlabeled adenosine. Each value represents the average obtained from the incubation of 3 groups of 10 normal (N) or 10 post-crush ( $P C)$ retinas.

$P<0.05$ ). No significant difference in TCA-soluble radioactivity was found in either the cytoplasmic or nuclear fractions at any time point, following incubation of retinas with saturating amounts of $\left[{ }^{3} \mathrm{H}\right]$ uridine.
Free and membrane-bound ribosomes in post-crush retinas

Figure 6 shows the differences following optic nerve crush in the labeling of retinal ribosomal RNA and 


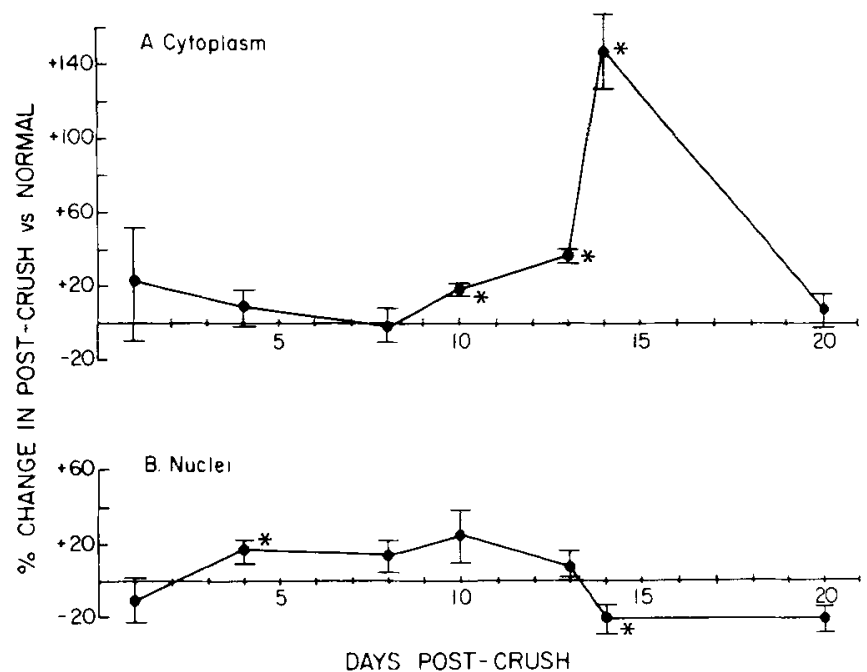

Fig. 5. Incorporation of $\left[{ }^{3} \mathrm{H}\right]$ uridine into poly(A)-containing RNA of post-crush retinas. Retinas were incubated as described in Fig. 3 with the addition of saturating amounts of unlabeled uridine. Each point is the average value obtained from the incubation of 3 groups of 10 normal or 10 post-crush retinas. RNA was extracted from the cytoplasmic and nuclear fractions and bound to nitrocellulose filters as a measure of poly(A)-containing RNA. An average 460 d.p.m. (cytoplasmic fraction) or 950 d.p.m. (nuclear fraction) were bound per filter for each group of 10 normal retinas. Asterisks mark significant differences $(P \leqq 0.05)$.

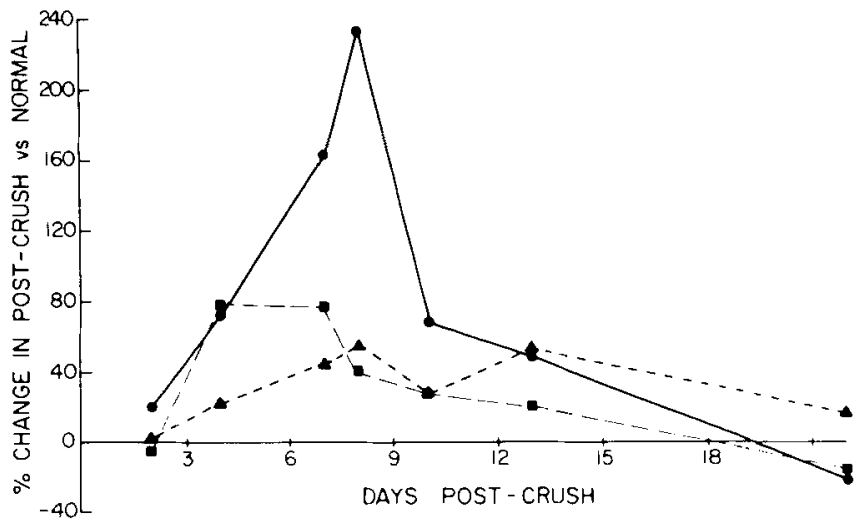

Fig. 6. $\left[{ }^{3} \mathrm{H}\right]$ uridine incorporation into retinal ribosomes and RNA precursor pools. Retinas were incubated in vitro as described in Fig. 3, then treated with hyaluronidase. Saturating amounts of precursor were not used-see text. Free and membrane-bound ribosomes were isolated as in Experimental Procedures. RNA precursor pool (TCA-soluble d.p.m./retina) measurements were made on portions of the unfractionated homogenates. Percent change in ribosome labeling was calculated on the basis of d.p.m./OD $/ \mathrm{D}_{260}$ unit. Each point represents 2 groups of $60-70$ retinas. Each group of normal retinas contained an average 44,500 d.p.m. $/ O D_{260}\left(0.26 \mathrm{OD}_{260}\right)$ in free ribosomes and 66,200 d.p.m. $/ \mathrm{OD}_{260}\left(0.27 \mathrm{OD}_{260}\right)$ in membrane-bound ribosomes. Free ribosomes, - -

Membrane-bound ribosomes, _- - _ - TCA-soluble fraction (RNA precursors). - -

of the RNA precursor pool. Saturating amounts of precursor were not used to insure sufficient amounts of labeled ribosomal RNA following extensive purification. A marked increase is observed in the incorporation of high specific activity $\left[{ }^{3} \mathrm{H}\right]$ uridine into free ribosomes of post-crush retinas peaking 8 days after axotomy (Fig. 6). A smaller effect, maximum from day 4 to day 7 , is seen in the membrane-bound fraction. Both changes appear greater than could be accounted for by the observed changes in the precursor pool radioactivity.

\section{DISCUSSION}

Among the earliest detectable biochemical events observed in the retina following axotomy (Fig. 7) are enhanced RNA precursor uptake and increased 


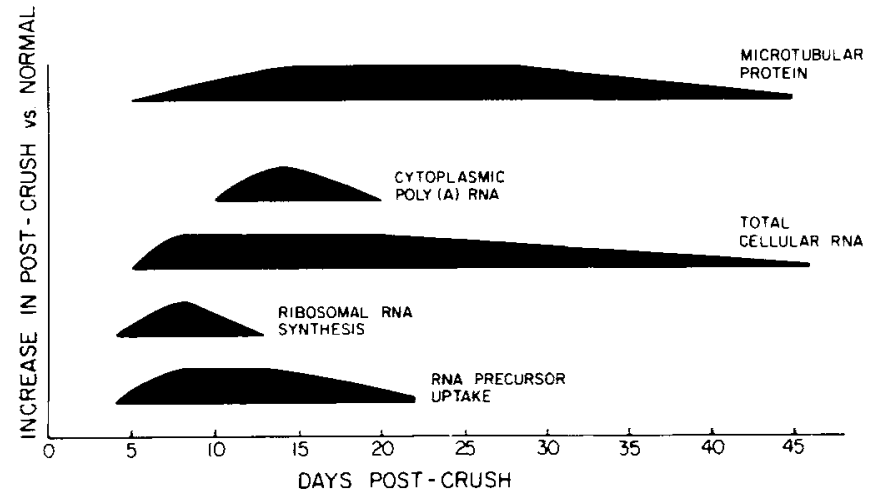

Fig. 7. Summary of temporal relationships of biochemical events in the retina related to optic nerve regeneration. Isotopic labeling patterns of various macromolecular fractions are compared with precursor uptake and total amount of retinal RNA.

ribosomal RNA isotopic labeling. These changes are accompanied by an increase in total retinal RNA and followed by an increase in cytoplasmic poly(A)containing RNA labeling. Our initial observation of an increase in total cellular RNA labeling by high specific activity precursors appears to be analogous to the findings of HORII \& VARON (1977). These investigators have suggested that a nerve growth factor (NGF)-dependent accumulation of nucleosides is responsible for the enhanced labeling of RNA in chick embryo dorsal root ganglion cells in response to this trophic factor; leucine uptake was unaffected by NGF. RozENGURT et al. (1977) have characterized a large increase in the rate of nucleoside incorporation into intracellular pools as an early response of 3T3 cells to growth stimulation by serum. Following optic nerve crush, the increase in nucleoside uptake in the goldfish retina may reflect a requirement of the ganglion cells for greater amounts of precursors to sustain an increased rate of RNA synthesis. It is also possible that the nucleosides regulate RNA synthesis. FERCHMIN et al. (1975) have reported that changes in intracellular nucleotide concentrations can regulate RNA polymerase II activity.

Comparison of the incorporation of labeled nucleosides into ribosomal RNA from normal and post-crush retinas (Fig. 6) suggests a marked increase in the synthesis of free ribosomes and to a lesser extent in the membrane-bound fraction during regeneration. As ribosomal RNA is particularly stable (13-15 day half-life in rats; KAHN \& WiLson, 1965) compared to other RNA species, it is not surprising that during the course of optic nerve regeneration, cellular RNA content decreases to control values much more slowly than does ribosomal RNA svnthesis. Our data correlate well with previous ultrastructural observations (MURRAY \& GRAFSTEIN, 1969 ; MURRAY \& Foreman, 1971) of increased Nisslstaining material (presumably membrane-bound ribosomes), nucleolar hypertrophy, and a proliferation of free ribosomes in the axotomized retinal ganglion cells. The labeled ribosome distribution seen in postcrush retinas is similar to the increase in free ribosomes observed in rapidly multiplying cells (Noll \& Burger, 1974; SCHNeIder et al., 1976) and may reflect qualitative shifts in the proteins synthesized during axonal regeneration. Free ribosomes are thought to synthesize proteins involved in cell metabolism, while the membrane-bound class are implicated in the synthesis of membrane proteins and proteins transported from the cell body (TAKAGI et al, 1970; Noll \& Burger, 1974; NABeshima et al., 1975).

As seen in Fig. 5A and 6, the isotopic labeling patterns of cytoplasmic poly(A)-containing RNA and ribosomal RNA during axonal regeneration are dissimilar; maximal ribosome biosynthesis occurs before the observed increase in mRNA. A temporal relationship between the periods of maximum isotopic labeling of ribosomal RNA and of 'messenger-like' RNA has recently been reported in the rat nodose ganglia following cervical crush of the vagus nerve (KAYE et al., 1977; GUnNing et al., 1977). The enhanced labeling of retinal cytoplasmic poly(A)containing RNA by $\left[{ }^{3} \mathrm{H}\right.$ ] adenosine 13 days after nerve crush in the present study reflects an increase in the RNA itself rather than in the $3^{\prime}$-terminal polyadenylate 'tail,' since no difference was found in the labeling of RNase-resistant material (Fig. 4). This conclusion is supported by the similar increase observed in cytoplasmic poly(A)-containing RNA labeling from $\left[{ }^{3} \mathrm{H}\right]$ uridine (Fig. 5A).

The appearance of increased amounts of labeled poly(A)-containing RNA in the retinal cytoplasm 10-14 days after axotomy could reflect an increase in its synthesis, a change in post-transcriptional RNA processing (for example, an elevated rate of conversion of pre-existing hnRNA to mRNA or increased transport of mRNA from the nucleus), or by a longer half-life in the cytoplasm. As shown in Fig. 5B. nuclear poly(A)-containing RNA labeling is significantly higher in post-crush retinas before it is seen 
in the corresponding cytoplasmic species, and decreases at the time of increasing cytoplasmic poly(A)containing RNA labeling. These data are consistent with a post-transcriptional alteration in mRNA processing within the nucleus at a defined period of axonal regeneration. In advancing such an interpretation, the results of several previous studies are noteworthy. WATSON (1965) has reported an increase in the transfer of labeled material from the nucleus to cytoplasm in regenerating mouse hypogloassal nerve after injection of labeled nucleosides. This initial increase in RNA transfer rate then decreased to a value below that of the control nerve and remained low until nerve maturation was completed.

An increase in cytoplasmic poly(A)-containing RNA is seen when neuroblastoma cells in culture 'differentiate' and acquire many of the characteristics of mature neurons, such as neurite formation, in response to agents that increase intracellular cyclic AMP concentration or block mitosis (PRASAD et al., 1975). As in post-crush retinas (Fig. 4A), no change is seen in the RNase-resistant portion of 'differentiating' neuroblastoma cytoplasmic poly(A)-containing RNA.

Comparison of changes in RNA metabolism during nerve regeneration with those observed during growth in culture and in chemically-induced carcinogenesis shows some similarities. Serum-induced growth in cultured 3T3 and 3T6 fibroblast cells is accompanied by a number of changes in RNA (JOHNSON et al,, 1974; ABELSON et al., 1974; JoHNSON et al., 1976). The cytoplasmic content of both ribosomal RNA and poly(A)-containing RNA increases several fold; however, no change in the rate of hnRNA synthesis is detected (JoHNSON et al., 1975). The authors concluded that the increase in mRNA levels during serum-induced growth is due to enhanced transfer of pre-existing nuclear poly(A)-containing RNA to the cytoplasm.

A parallel may also be drawn between these results and the report of increased levels of rat liver cytoplasmic RNAs that contain polyadenylate sequences after treatment with the hepatocarcinogen, thioacetamide (SMUCKLER \& KOPLITZ, 1974; 1976). This increase was interpreted as reflecting relaxation of stringent control of RNA processing in the nucleus during carcinogenesis.

Although the ganglion cells are large, they undoubtedly contain only a fraction of the total retinal RNA. If all of the observed alterations following axotomy are restricted to these cells, as histological evidence appears to indicate, the changes seen in whole retina represent a much larger alteration within the ganglion cells themselves. The same can be said for changes in retinal protein labeling following axotomy. Furthermore, an increase in mRNA and ribosome content in retinal ganglion cells might be expected to precede an increase in protein synthesis. Radioautographic evidence for an increased incorporation of $\left[{ }^{3} \mathrm{H}\right]$ leucine into retinal ganglion cell proteins after optic nerve transection has been reported (MURRAY \& GRAFSTEIN, 1969). This observation suggests that these cells mediate the enhanced isotopic labeling of microtubular protein seen in post-crush retinas (Heacock \& AGRanoff, 1976). Although the increase in radiolabeling of microtubular protein is detected prior to the earliest observation of an increase in labeled retinal cytoplasmic poly(A)-containing RNA following axotomy (Fig. 7), this inversion of the anticipated sequence of events may be attributed to the greater sensitivity by which changes in labeling of specific proteins can be measured compared to that of a corresponding mRNA.

Unlike the findings with RNA, no change in total retinal protein content is observed during axonal regeneration (Fig. 2). This may reflect the fact that in vivo, much of the new protein leaves the ganglion cells by axonal flow via the newly regenerated optic nerve. Previous studies (Grafstein \& Murray, 1969 ; Frizell \& SJostrand, 1974; Hoffman \& LASEK, 1975) have indicated that increased incorporation of amino acids into neuronal cell body protein is accompanied by a greater axonal transport of labeled protein in the regenerating axon. While there is also increased labeled RNA transport out of the retina (INGOGLIA et al., 1975), this is quantitatively less significant.

The present study has shown that changes in retinal RNA metabolism, including increased precursor uptake, ribosome accumulation, and altered posttranscriptional regulation of $\mathrm{mRNA}$ are concomitants of optic nerve regeneration in the goldfish. A comparison of these results with previous findings indicates that during axonal regeneration, the goldfish retina shares many of the changes in RNA reported in cells undergoing mitosis, in cellular differentiation and in neoplasia.

Acknowledgements-The authors wish to acknowledge the expert technical assistance of MARIANNE ANDREWs, as well as the help of Dr. ANNE HEACOCK in a critical evaluation of the manuscript

\section{REFERENCES}

Abelson H. T., Johnson L. F., Penman S. \& Green H. (1974) Cell 1, 161-165.

AdesniK M., Salditt M., Thomas W. \& Darnell J. E. (1972) J. molec. Biol. 71, 21-30.

Bantle J. A., Maxwell I. H. \& HahN W. E. (1976) Analyt. Biochem. 72, 413-427.

Brawerman G. (1974) in Methods in Enzymology (Moldave K. \& Grossman L., eds.) Vol. 30, pp. 605-612. Academic Press, New York.

Brawerman G. (1976) in Prog. Nuc. Acid Res. Molec. Biol. (CoHN W. ed.) Vol. 17, pp. 117-148. Academic Press. New York.

Burton K. (1968) in Methods in Enzymology (Moldave K. \& Grossman L., eds.) Vol. 12, Part B, pp. 163-166. Academic Press. New York.

Cragg B. G. (1970) Brain Res. 23, 1-21.

Darnell J. E., Philipson L.. Wall R. \& Adesnik M. (1971) Science 174, 507-510. 
DUNLOP D. S., VAN Elder W. \& LAJTHA A. (1974) J. Neurochem. 22, 821-830.

Ferchmin P. A., Morimoto H. \& Bennett E. L. (1975) J. Neurochem. 25, 437-443.

Frizell M. \& Siostrand J. (1974) Brain Res. 81, 267-283.

Grafstein B. (1975) Exp. Neurol, 48, 32-51.

Grafstein B. \& MURRAY M. (1969) Exp. Neurol. 25, $494-508$.

Gunning P. W., Kaye P. L. \& Austin L. (1977) J. Neurochem. 28, 1245-1248.

Heacock A. M. \& Agranoff B. W. (1976) Proc. natn Acad. Sci., U.S.A. 73, 828-832.

Hoffman P. N. \& LASEK R. J. (1975) Neurosci. Abstr. 1 , 807.

HoRII Z. I. \& VARON S. (1977) Brain Res. 124, 121-133.

INGOGLiA N. A. \& TUliszewsKI R. (1976) Brain Res. 112, 371-381.

Ingogli N. A., Weis P. \& Mycek J. (1975) J. Neurobiol. 6. 549-563.

JACOBSON M. \& GAZE R. M. (1965) Exp. Neurol. 13,418-430.

Johnson L. F., Abelson H. T., Green H. \& Penman S. (1974) Cell 1, 95-100.

Johnson L. F., Levis R., Abelson H. T., Green H. \& Penman S. (1976) J. Cell Biol. 71, 933-938.

Johnson L. F., William J. G., Abelson H. T., Green H. \& Penman S. (1975) Cell 4, 69-75.

JONES G. H. (1976) Biochem biophys. Res. Commun. 69 , 469-474.

Kaye P. L., Gunning P. W. \& Austin L. (1977) J. Neurochem. 28, 1241-1243.

Khan A. A. \& WiLson J. E. (1965) J. Neurochem. 12, 81-86.

LARKINS B. A., Jones R. A. \& TSAI C. Y. (1976) Biochemistry. 15, 5506-5511.

Lee S. Y., Mendecki J. \& Brawerman G. (1972) Proc. natn. Acad. Sci., U.S.A. 68, 1331-1335.

Lieberman A. R. (1971) Int. Rev. Neurobiol 14, 49-124.

LIN R. I. \& SCHuEIDE O. A. (1969) Analyt. Biochem. 27, 473-483.

LOWRy O. H., Rosebrough N. J., Farr A. L. \& RaNdal. R. J. (1951) J. biol. Chem. 193, 265-275.
Mans P. J. \& Novelli G. D. (1961) Archs. Biochem. Biophys. 94, 48-53.

Molloy G. R., Jelinek W.. Salditt M. \& Darnell J. E. (1974) Cell. 2, 43-53.

Murkay M. (1973) Exp. Neurol. 39, 489-497.

Murray M. \& Forman D. S. (1971) Brain Res. 32, 287-298.

Murray M. \& Grafsteln B. (1968) Anat. Record. 160, 398.

Murray M. \& Grafstein B. (1969) Exp. Neurol. 23, 544-560.

Nabeshima Y-I., Tsurugi K. \& Ogata K. (1975) Biochem. biophys. Acta 414, 30-43.

Noll M. \& Burger M. M. (1974) J. molec. Biol. 90, 215-236.

Perry R. P., Latorre J., Kelly D. E. \& Greenberg J. R. (1972) Biochem. biophys. Acta. 262, 220-226.

Prasad K. N., Bondy S. C. \& Purdy J. L. (1975) Exp. Cell Res. 94, 88-94.

Ramsey J. C. \& Steele W. J. (1976) Biochemistry 15, 1704-1712.

Rozengurt E., Stein W. D. \& Wigglesworth N. M (1977) Nature 267, 442-444.

SANTEN R. J. \& AGRanoff B. W. (1963) Biochim. biophys. Acta 72, 251-262.

SChNeider E., LochmanN E-F. \& Lother H. (1976) Biochim. biophys. Acta 432, 92-97.

Smuckler E. A. \& Koplitz M. (1974) Cancer Res. 34, 827-838.

Smuckler E. A. \& Koplitz M. (1976) Cancer Res. 36, $881-888$.

Springer A. D. \& Agranoff B. W. (1977) Brain Res. 128, 405-415.

TaKaGi M., TanaKa T. \& OGata K. (1970) Biochim. biophys. Acta 217, 148-158.

TorviK A. \& SkJÖrTEN F. (1974) J. Neurocytol. 3, 87-97.

WATSON W. E. (1965) J. Physiol. 180, 741-753.

Zomzely-Neurath C. E. \& Roberts S. (1972) in Research Methods in Neurochemistry (MARKs M. \& RODNIGHT R., eds.) Vol. 1, pp. 95-137. Plenum Press, New York. 